\title{
Sustainable construction through Eco-efficient ultra-high performance concrete
}

\author{
I. Ferdosian \& A. Camões \\ Center of territory, Environment and construction $(C-T A C)$, civil Engineering department, University of \\ Minho, Guimarães, Portugal
}

\begin{abstract}
An innovative type of steel-fibre reinforced ultra-high performance concrete (UHPC), including its constituent materials and its mixing procedure, is reviewed in this paper. Furthermore, an energy-efficient curing method for developing precast UHPC members is presented as the main goal of the current study. It was found that just with 24 hours of curing in tempered water or steam with $67^{\circ} \mathrm{C}, 95 \%$ of 28 -day compressive strength in normal curing method, $145 \mathrm{MPa}$, could be achieved which would be of great interest for prefabrication industry regarding their energy consumption. It also would be beneficial for any project in which early load-bearing capacity is expected. Self-compactness, compressive strength higher than $150 \mathrm{MPa}$, improved durability and finally low curing energy in precasting phase of the material all offer variety of slim interior and exterior architectural and structural applications even in high-rise structures and aggressive environments where higher strength, ductility and durability is required.
\end{abstract}

\section{INTRODUCTION}

It was in 1995 that the first UHPC composition was introduced under the title of Reactive powder concrete (RPC) (Richard \& Cheyrezy, 1995). Afterwards, parallel investigations were carried out resulting in Ductal ${ }^{\circledR}$ as one of the known commercially available types of UHPC (Acker \& Behloul, 2004). The first application of this material was the 60-meter span Sherbrooke footbridge in Quebec, built in 1997 (Blais \& Couture, 1999). Some other applications of UHPC are provided in Table 1-1. Beside that, some structural and architectural projects made of UHPC are shown in Figure 1.1.

Table 1-1: First applications of UHPC.

\begin{tabular}{|c|c|c|c|}
\hline Project & year & Location & Reference \\
\hline $\begin{array}{l}\text { Sherbrooke Pedestrian Overpass, Quebec, Precast, post- } \\
\text { tensioned space truss, } 60 \text { meter span }\end{array}$ & 1997 & Canada & $\begin{array}{l}\text { (Blais \& Couture, } \\
\text { 1999) }\end{array}$ \\
\hline $\begin{array}{l}\text { World first industrial applications, Cattenom and Civaux } \\
\text { power plants beams by BSI } \AA \text { and Ductal } \AA\end{array}$ & 1998 & France & (Resplendino, 2004) \\
\hline $\begin{array}{l}\text { world first UHPC road bridges on the Bourg-lès-Valence } \\
\text { bypass in France's Drôme region }\end{array}$ & 2001 & France & (Hajar, et al., 2004) \\
\hline Sunyudo (Peace) Footbridge on Han river in Seoul. & 2002 & $\begin{array}{l}\text { South } \\
\text { Korea }\end{array}$ & $\begin{array}{l}\text { (Behloul, et al., } \\
\text { 2002) }\end{array}$ \\
\hline Akakura (Yamagata) footbridge box girder & 2004 & Japan & $\begin{array}{l}\text { (Rebentrost \& } \\
\text { Wight, 2008) }\end{array}$ \\
\hline
\end{tabular}




\begin{tabular}{lcll}
\hline Tahara (Aichi) Footbridge & 2004 & Japan & $\begin{array}{l}\text { (Rebentrost \& } \\
\text { Wight, 2008) }\end{array}$ \\
\hline $\begin{array}{l}\text { Mars Hill Bridge, Wapello County, IA Three 1.1- m deep } \\
\text { bulb-tee beams with 33.5 m Span }\end{array}$ & 2006 & $\begin{array}{l}\text { United } \\
\text { States }\end{array}$ & $\begin{array}{l}\text { (Bierwagen \& Abu- } \\
\text { Hawash, 2005) }\end{array}$ \\
\hline $\begin{array}{l}\text { Highway 11 over CN Railway at Rainy Lake, Ontario, } \\
\text { Joints between precast panels and shear connector panels }\end{array}$ & 2006 & Canada & (Perry, et al., 2007) \\
\hline $\begin{array}{l}\text { Glenmore/Legsby Pedestrian Bridge, Calgary, Precast, } \\
\text { post-tensioned tee-section }\end{array}$ & 2007 & Canada & $\begin{array}{l}\text { (Perry \& Seibert, } \\
\text { Highway 11/17, Sunshine Creek, Ontario, Joint fill be- } \\
\text { tween adjacent box beams and between precast curbs }\end{array}$ \\
\hline
\end{tabular}

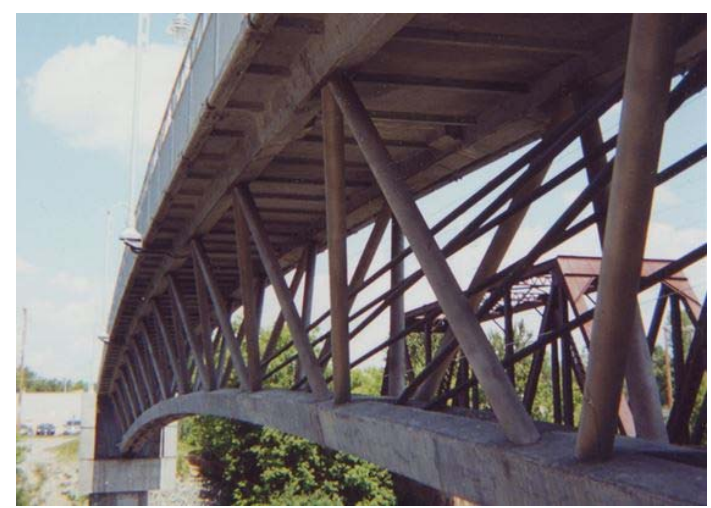

a)

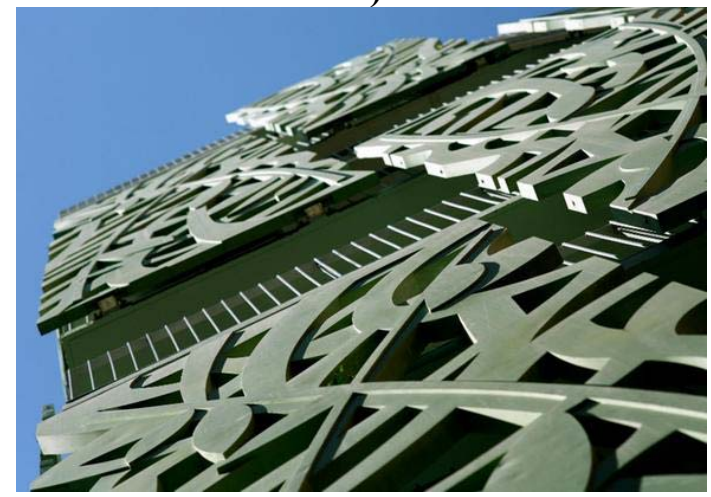

c)

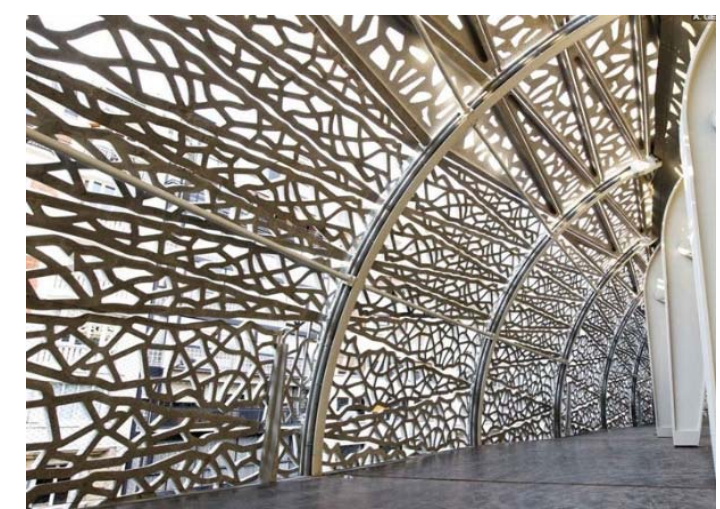

b)

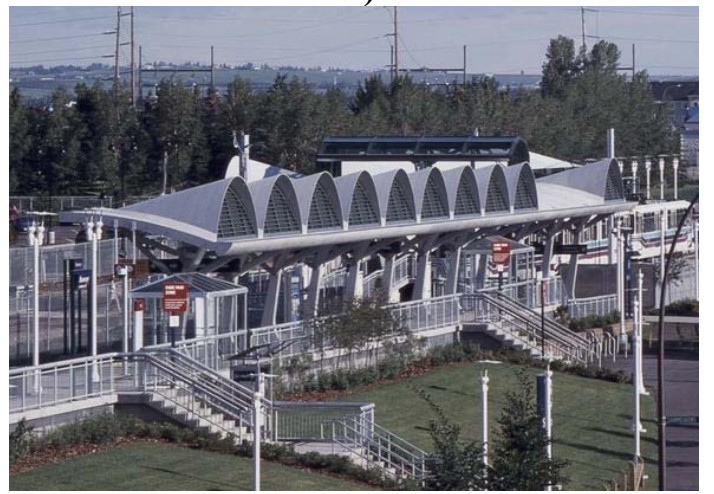

d)

Figure 1.1. a) Sherbrooke Pedestrian Overpass; b) Delicate veil façade made of Ductal ${ }$, Jean Bouin stadium in Paris (Lafarge, 2013); c) Mineral leaf decor for a vertical landscape, ZAC Paris Rive Gauche, France (Lafarge, 2009); d) The Shawnessy LRT Station, Calgary, Canada, with canopy Roof System (Vicenzino, et al., 2005).

To obtain UHPC some basic principles should be considered such as elimination of coarse aggregates and improving the packing density of the matrix (Richard \& Cheyrezy, 1995). To achieve this, in most of known UHPC compositions, cement, silica fume, filler such as glass powder or silica powder, fine sand, super-plasticizer, steel fiber and water are being used as the main constituent materials. Beside this, mixing method of the constituent materials should be carefully studied since it plays an important role in flowability and workability of the material in its fresh state. For instance wille et al. (2012) applied a 15 minutes mixing method including 5 minutes sand and silica fume, 5 minutes cement and glass powder and more 5 minutes after adding water and superplasticizer (Wille, et al., 2012). Since the water/binder is very low in UHPC, another major step is to prevent waterscape from the exposed surface. Otherwise, early-age cracking in dehydrated surface and its degradation-related issues would be uncontrollable (Graybeal, 2011). In addition to this matter and as a result of simultaneous hydration of cement particles, resulting in autogenous shrinkage of UHPC, access to external water through one of the water curing methods, such as fogging or water pounding, immediately after casting and finishing the concrete, particularly during the age of 12 hours to 7 days, would be critical (Aitcin, 1998). Steam curing 
also immunes UHPC to durability-related issues such as freeze-thaw and chloride ion penetration (Graybeal, 2006).

The main advantages of UHPC as a high-tech architectural and structural material include:

- Installation process of lightweight UHPC members, including handling and transportation, would be more convenient and safer.

- By elimination of a significant part of the reinforcement bars and stirrups, considerable human labors, supervision tasks and quality control activities could be decreased beside reduction of permanent load resulting in lighter structures (Richard \& Cheyrezy, 1995).

- Improved tensile behavior compared to other types of concrete resulted from internal fibers (Voo, et al., 2006)

- Due to its higher strength rather than normal concretes, UHPC could be recycled at the end of its life-cycle as high-quality aggregates for new generation of concretes resulting in lower extraction of natural resources beside enhanced durability, which all cause longer service life (Aïtcin, 1998; Voo \& Foster, 2010).

- Extraordinary slim designs as the result of high strength and ductility (Acker \& Behloul, 2004).

However due to high durability and other mechanical performances of this material it could be considered as an eco-friendly material in long term, more attempts to improve its cost and environmental efficiency are required.

\section{CONSTITUENT MATERIALS}

Type I Portland cement (CEM I 42.5R according to EN 197-1 (BS EN 197-1, 2000)) and metakaolin (MK) with $9.3 \mu \mathrm{m}$ and $8 \mu \mathrm{m}$ of average particle size respectively were studied. The silica fume (SF) from Elkem Microsilica ${ }^{\circledR}$ MS 940-U with an average particle size of $0.15 \mu \mathrm{m}$ and an fly ash (FA) provided from Pego thermal power unit, a Portuguese coal based one, with $8.55 \mu \mathrm{m}$ average particle size were also used in this research. A siliceous micro-sand, delivered from Rio Maior in Portugal, with a maximum size close to $1 \mathrm{~mm}$ was also applied. Some physical properties and chemical analysis of the materials are reported in Table 2-1. The particle size distribution of the materials is depicted in

Figure 2.1. A commercial superplasticizer (SP), MasterGlenium SKY 526®, with $30 \%$ of solid content was also used. The SP (Table 2-2) is a carboxylic ether polymer based as a brown liquid with properties according the definitions and requirements of Standard EN 934-2, established for European concrete admixtures (BS EN 934-2, 2009). The micro steel fiber applied here has a length/dimeter ratio of 65 with $2600 \mathrm{MPa}$ of tensile strength.

Table 2-1. Chemical and physical compositions of cement, SF, MK and FA.

\begin{tabular}{lllll}
\hline Components & \multicolumn{3}{c}{$\mathrm{w}_{\mathrm{t}} \%$} \\
\cline { 2 - 5 } & $\mathrm{CEM} 42.5 \mathrm{R}$ & $\mathrm{MS} 940-\mathrm{U}$ & $\mathrm{MK}$ & $\mathrm{FA}$ \\
\hline $\mathrm{SiO}_{2}$ & 19.79 & $>90$ & 50.50 & 48.02 \\
\hline $\mathrm{Al}_{2} \mathrm{O}_{3}$ & 4.37 & - & 42.60 & 29.59 \\
\hline $\mathrm{Fe}_{2} \mathrm{O}_{3}$ & 3.52 & - & 2.28 & 4.48 \\
\hline $\mathrm{CaO}$ & 63.09 & - & 0.16 & 4.65 \\
\hline $\mathrm{MgO}$ & 1.67 & - & 0.22 & 1.44 \\
\hline $\mathrm{SO}_{3}$ & 2.82 & - & 0.04 & 0.49 \\
\hline $\mathrm{Cl}^{-}$ & 0.04 & - & - & - \\
\hline loss of ignition & 3.01 & $<3$ & - & 3.0 \\
\hline Blaine surface area $\left(\mathrm{cm}^{2} / \mathrm{g}\right)$ & 4228 & $150000-300000$ & - & 3848 \\
\hline Specific gravity $\left(\mathrm{g} / \mathrm{cm}^{3}\right)$ & 3.1 & $2.2-2.3$ & 2.3 & 2.4 \\
\hline
\end{tabular}

Table 2-2.Technical characteristics of Superplasticizer MasterGlenium SKY 526®.

\begin{tabular}{ll}
\hline Relative density $\left(20^{\circ} \mathrm{C}\right)$ & $1.07 \pm 0.02 \mathrm{~g} / \mathrm{cm}^{3}$ \\
$\mathrm{pH}$ & $6.0 \pm 1.0$ \\
\hline Chloride ion content & $\leq 0.1 \%$ \\
\hline Solid content & $30 \%$
\end{tabular}




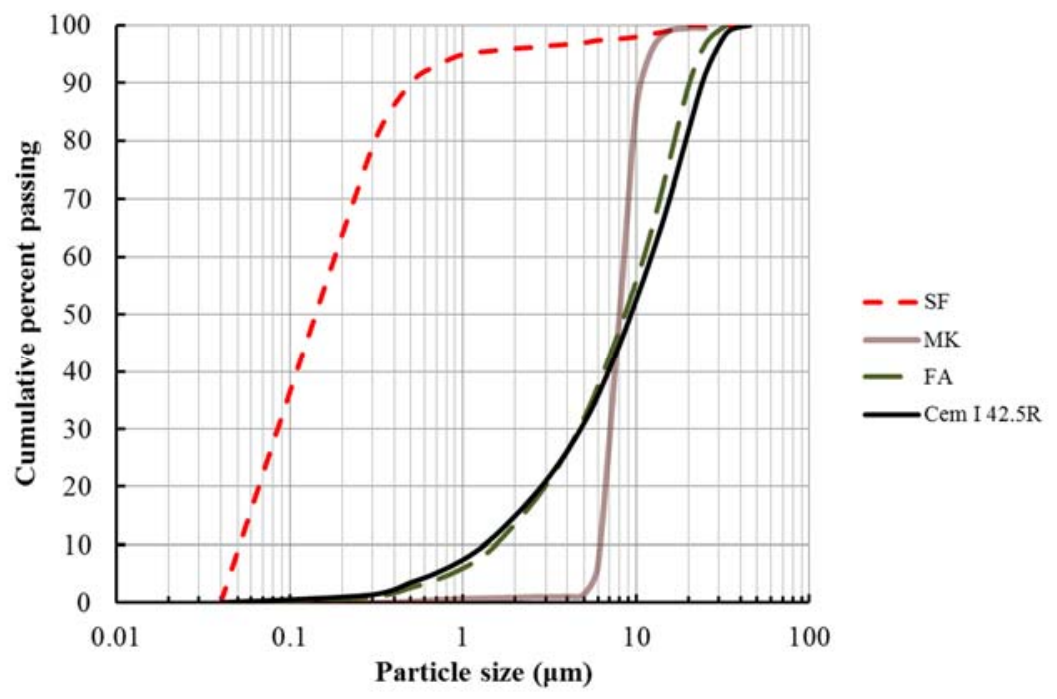

Figure 2.1.Cumulative particle size distribution of SF, MK, FA and Cement I 42.5R with average particle size of $0.15,8,8.55$ and $9.3 \mu \mathrm{m}$ respectively.

In the first phase of this study, metakaolin, fly ash and silica fume as three accessible pozzolanic materials were studied with the aim of cement substitution. It was found that metakaolin reduces workability considerably while fly ash and silica fume have the ability to be applied in UHPC. Nevertheless, regarding the high price of silica fume, it was also replaced by fly ash to an applicable extent. The reason why fly ash and silica fume do not degrade the workability compared to metakaolin could be their glassy and spherical particles, as shown in

Figure 2.2, which facilitate the sliding of other powders during casting while metakaolin particles have an angular surface with increasing the friction between particles. In addition, due to the smaller particle sizes of fly ash and silica fume compared to cement and sand they could fill the voids between sand and cement particles resulting higher packing density as well as compressive strength. Fly ash also plays an important role in cost efficiency of the material with respect to its lower price compared to cement and silica fume however, its effect regarding eco-efficiency is more considerable. More information regarding the constituent materials and their percentages is beyond the aim of this paper, which is studying the effect of two curing methods on strength-gain trend of the material, and could be found in other publications by authors.

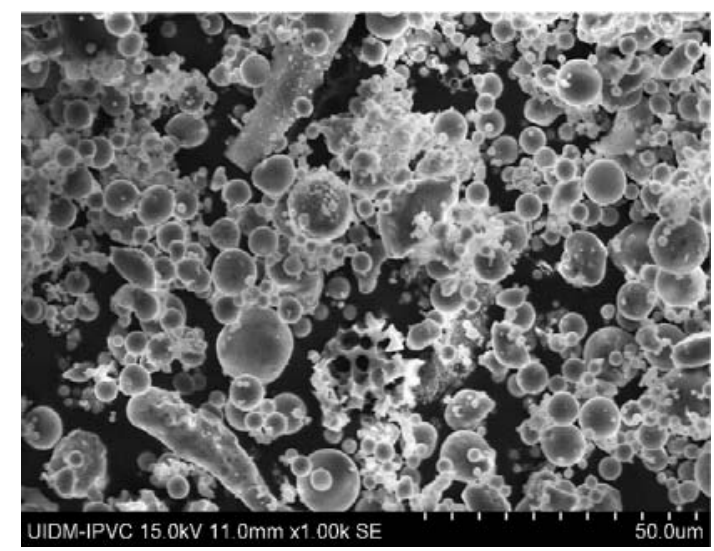

Figure 2.2. Low magnified SEM image of FA particles. 


\section{MIXING PROCEDURE AND SAMPLE PREPERATION}

An effective low-energy mixing procedure was also studied during this research. It was found that the best flow characteristics could be acquired after adding $70 \%$ of mixing water to the dry material and mixing for 3 minutes. It should be followed by adding the optimum dosage of SP and mixing for at least 4 minutes, 6 minutes seems preferable based on visual assessment, and finally adding the remaining $30 \%$ of water and blending for an extra 6 minutes to reach a steadystate consistency. The fibers are usually added at the end of this stage with continuing the mixing for another one minute (Ferdosian \& Camões, 2016).

After mixing, the flow-ability of the fresh concrete evaluated by means of flow table for mortars according to EN 1015-3 (BS EN 1015-3, 2004) (See

Figure 3.1). Once a steady state of flow was observed, after rising up the mini-slump cone, two perpendicular dimensions of expanded concrete were registered. Since self-compactness of UHPC is a prerequisite, the average of these measurements, without dropping the table, was registered as criteria for flowability. Based on this method, the material exhibited $19 \mathrm{~cm}$ of flow diameter in average.

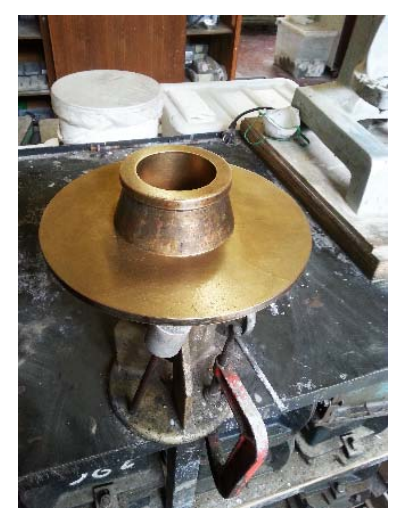

a)

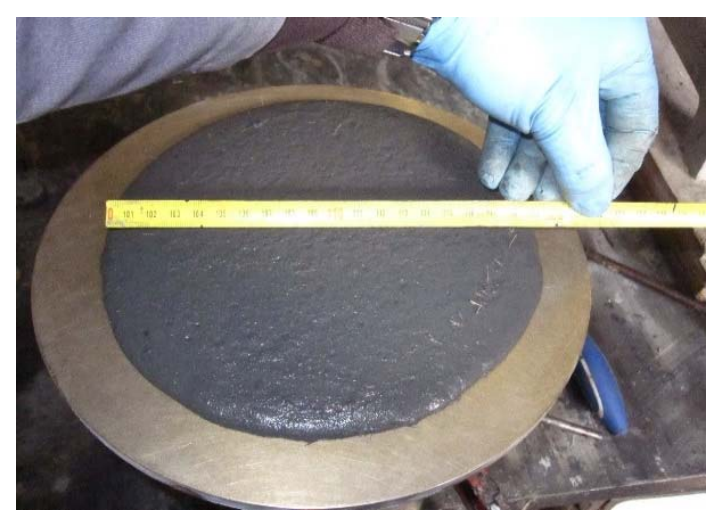

b)

Figure 3.1. Flow table test apparatus (a) and flow diameter after test (b).

All compressive tests performed in this study are according to standard test method for $50 \mathrm{~mm}$ cubic specimens (ASTM C109/C109M - 05, 2005) with a pace of $2.4 \mathrm{KN} / \mathrm{S}$. After measuring the flow diameter of fresh concrete, the reminded material on the table placed back to the mixing pan and mixed by hand for 20 seconds. Since the concrete had enough fluidity, it directly was transferred from mixer to the molds without any tools such as scoop. The casting of all specimens was performed on a vibration table. They were allowed to remain on vibration table for 20 seconds. Afterwards, their surfaces were smoothed with a trowel and covered with a thin plastic sheet to prevent any water loss from the exposed surface.

\section{CURING METHOD}

In the next part of this study, two curing methods were applied. The first method is normal curing in $20^{\circ} \mathrm{C}$ water bath until the day of compression test. The second method, known as temperedwater curing, is based on the introduced curing cycle as depicted in Figure 4.1. As can be seen, a delay period of 24 hours before starting the temperature rise is necessary. A delay period lower than concrete setting time may causes deteriorative effects as reported by other researchers (Alexanderson, 1972; Erdem, et al., 2003). The other significant issue in this curing method is the heating and cooling rate as stated by (ACI Committee 517, 1980). The final issue is to adjust the maximum treatment temperature. It has been stated that delayed ettringite formation, which generally starts after hardening of the concrete, is a result of concrete temperature higher than $70^{\circ} \mathrm{C}$ because of curing as well as heat of hydration in mass concretes, which finally affect the mechanical properties of concrete (Taylor, et al., 2001). In this regard, $67^{\circ} \mathrm{C}$ was selected as maximum 
treatment temperature in current study. To investigate the effect of different treatment time intervals on the strength-gain trend, the samples were tested after 24, 48, 72, 144 and 168 hours of treatment.

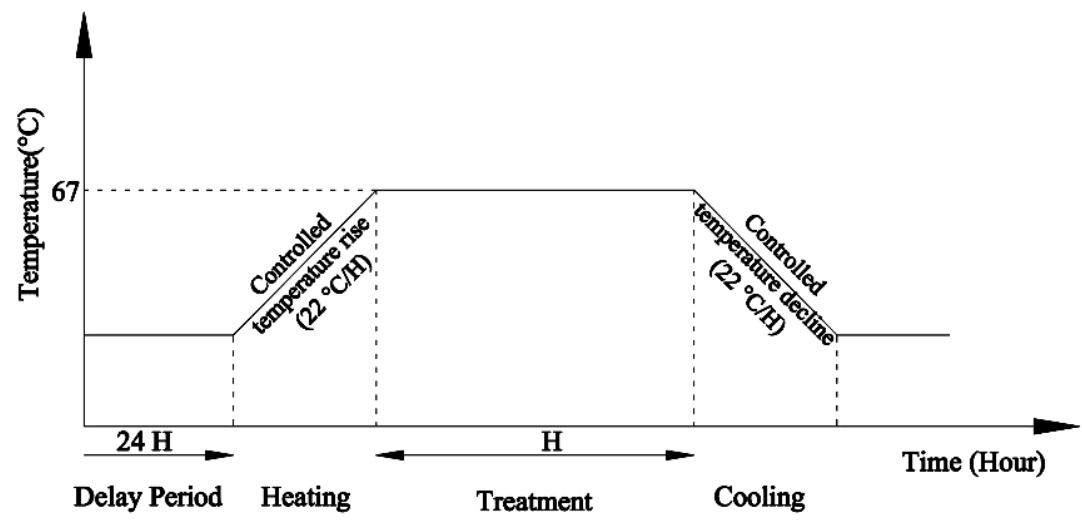

Figure 4.1. Tempered-water-curing cycle for specimens

As shown in

Figure 4.2, 28-day compressive strength of normal-cured samples, $152 \mathrm{MPa}$, is $88 \%$ of its final strength, which could be used for any design purposes. In addition, as depicted in

Figure 4.3, 48 hours of heat curing in tempered-water method ensures an acceptable compressive strength higher than the 28-day strength of normal-cured specimens. Nevertheless, even 24 hours of treatment would be also acceptable in cases where $95 \%$ of the 28 -day strength is enough for load-carrying purposes. After 48 hours, the increasing trend of strength-gain becomes almost negligible. Although with just 48 hours of curing in tempered water the compressive strength goes slightly beyond the related value for 28-day in normal curing method, its final strength remains lower than normal-cured ones.

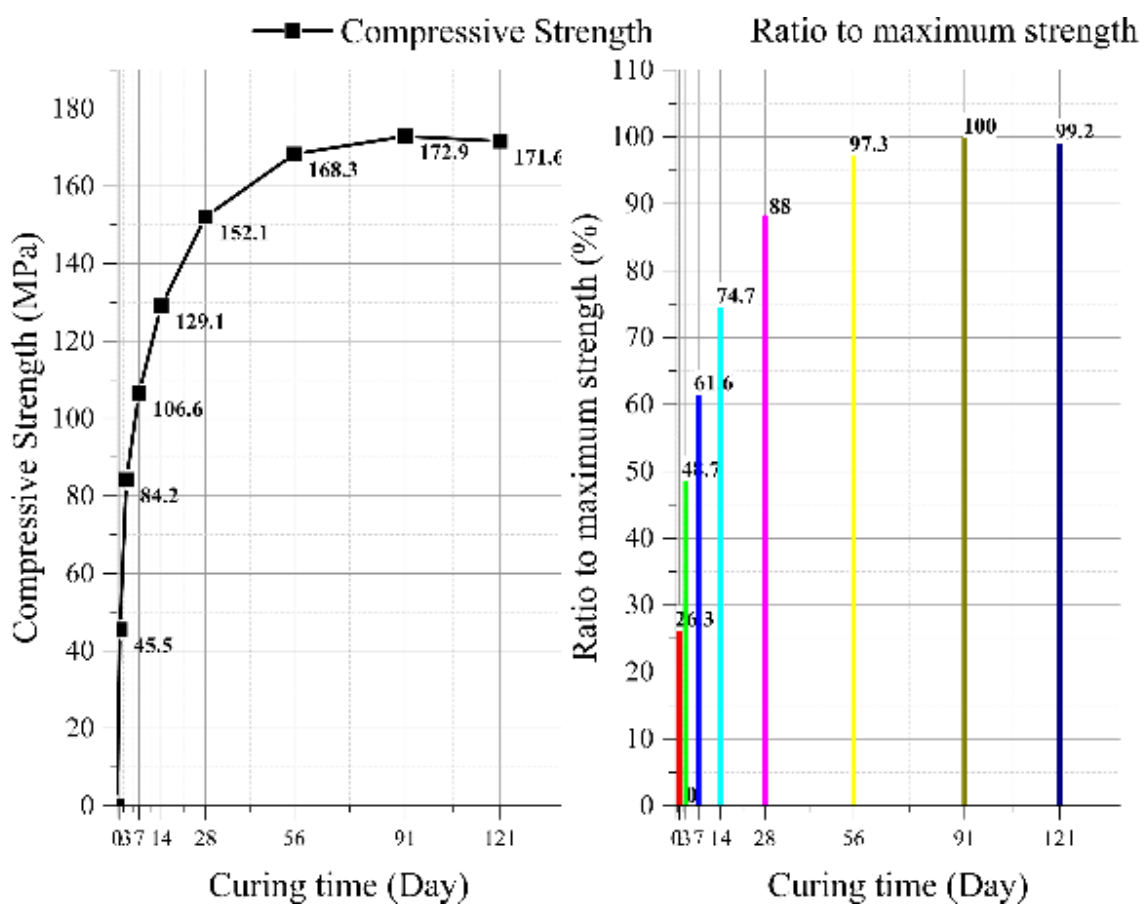

Figure 4.2. Compressive strength trend and the ratios of each age to maximum strength for normal-cured samples. 

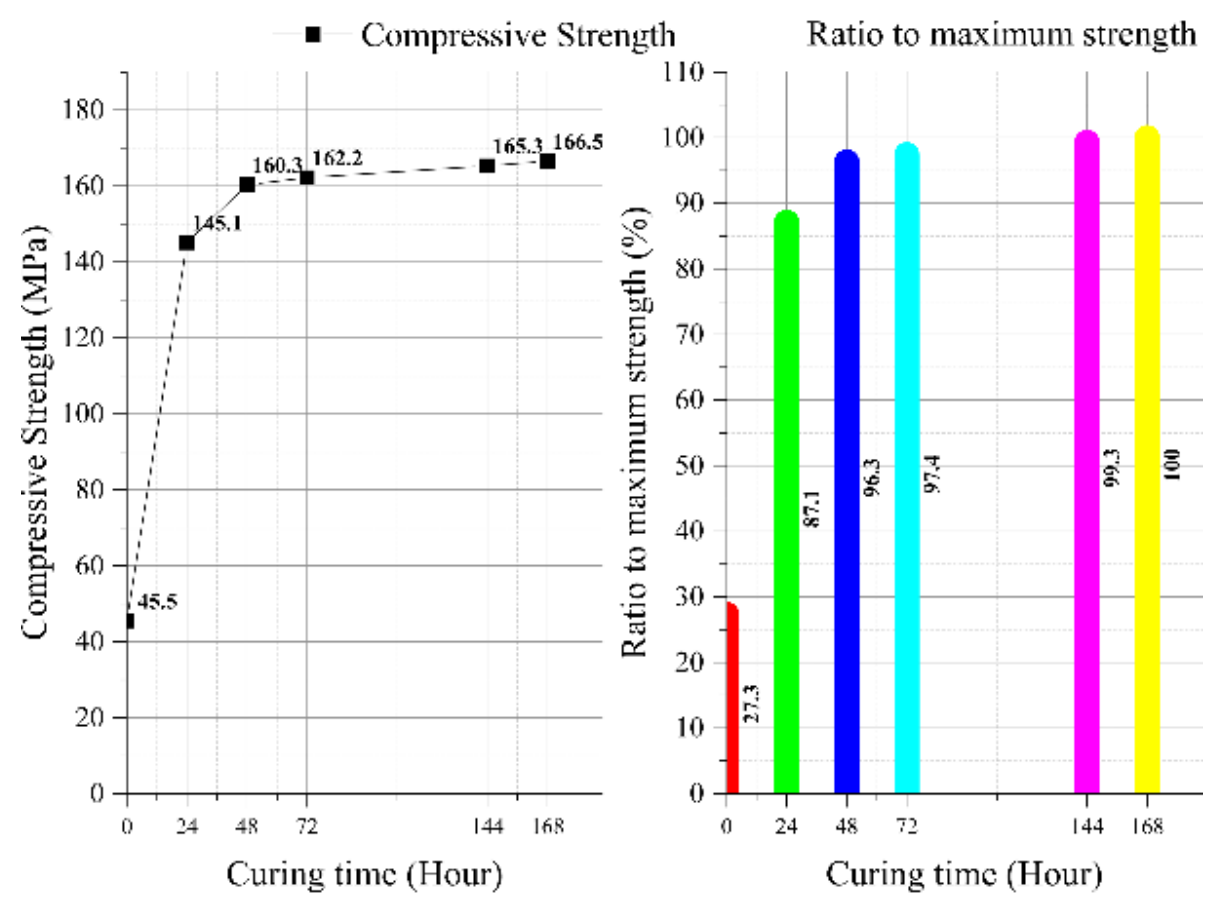

Figure 4.3. Compressive strength trend and the ratios of each age to maximum strength for tempered-watercured samples.

\section{CONCLUSION}

An overview on ultra-high performance concrete (UHPC), its applications and benefits as well as basic principles and methods regarding its material development was carried out in the first part of the current paper. Several pozzolanic materials namely silica fume, fly ash and metakaolin were introduced and compared with respect to their effects on UHPC. It was clarified that metakaolin is not a proper pozzolanic material for UHPC development since it affects the fresh behavior of the material beside the fact that it bears high $\mathrm{CO}_{2}$ content. On the other hand, fly ash has shown its ability for cement and silica fume substitution. In addition, an efficient mixing procedure resulting in maximum flowability of the material in its fresh state was introduced. Finally, two different curing methods were described and compared as the main goal of this paper. It was found that even 24 hours of tempered-water curing in $67^{\circ} \mathrm{C}$ and after 24 hours of delay period between molding time and temperature rise could results in a compressive strength of 145 MPa which is $95 \%$ of its strength after 28 days of normal curing. This provides and energy-efficient curing procedure for prefabrication industry and improves the eco-efficiency of UHPC.

\section{REFERENCES}

ACI Committee 517, 1980. Accelerated Curing of Concrete at Atmospheric Pressure-State of the Art. $A C I$ Journal Proceedings, 77(6), pp. 429-448.

Acker, P. \& Behloul, M., 2004. Ductal ${ }^{\circledR}$ Technology: a Large Spectrum of Properties, a Wide Range of Applications. Kassel, Germany, kassel university press, pp. 11-23.

Aitcin, P.-C., 1998. The Art and Science of High-Performance Concrete. INDUSTRIA ITALIANA DEL CEMENTO, pp. 350-365.

Alexanderson, J., 1972. STRENGTH LOSSES IN HEAT CURED CONCRETE. s.1., Swedish Cement Concr Inst Proc.

ASTM C109/C109M - 05, 2005. Standard Test Method for Compressive Strength of Hydraulic Cement Mortars (Using 2-in. or [50-mm] Cube Specimens). ASTM International, West Conshohocken, PA 19428-2959, United States, Patent No. ASTM C109/C109M - 05. 
Behloul, M., Causse, G. \& Etienne, D., 2002. Passerelle en Ductal ${ }^{\circledR}$ de Séoul/Ductal $®$ footbridge in Seoul. Osaka, Japan, Association Française de Génie Civil, fédération internationale du béton (AFGC, FIB), pp. 33-34.

Bierwagen, D. \& Abu-Hawash, A., 2005. Ultra High Performance Concrete Highway Bridge. Ames, IA, Iowa State University.

Blais, P. Y. \& Couture, M., 1999. Precast, Prestressed Pedestrian Bridge - World's First Reactive Powder Concrete Structure. PCI JOURNAL, Volume 44, pp. 60-71.

BS EN 1015-3, 2004. Methods of test for mortar for masonry - Part 3: Determination of consistence of fresh mortar(by flow table). s.l.

BS EN 197-1, 2000. BS EN 197-1, Cement - Part 1 Composition,specification and conformity criteria for common cements. s.1.:s.n.

BS EN 934-2, 2009. Admixtures for concrete, mortar and grout. Concrete admixtures. Definitions, requirements, conformity, marking and labelling. s.l.

Erdem, T., Turanli, L. \& Erdogan, T., 2003. Setting time: An important criterion to determine the length of the delay period before steam curing of concrete. Cement and Concrete Research, Volume 33, pp. 741745.

Ferdosian, I. \& Camões, A., 2016. Effective low-energy mixing procedure to develop high-fluidity cementitious pastes. Matéria (Rio J.), 21(1).

Graybeal, B., 2009. Structural Behavior of a Prototype Ultra-High Performance Concrete Pi-Girder, s.l.: FHWA, U.S. .

Graybeal, B., 2011. Ultra-High Performance Concrete, s.1.: Federal Highway Administration(FHWA).

Graybeal, B. A., 2006. Material Property Characterization of Ultra-High Performance Concrete, McLean, VA: FHWA, U.S.

Hajar, Z., Lecointre, D., Simon, A. \& Petitjean, J., 2004. Design and Construction of the world first UltraHigh Performance Concrete road bridges. Kassel, Germany, Kassel University Press, pp. 39-48.

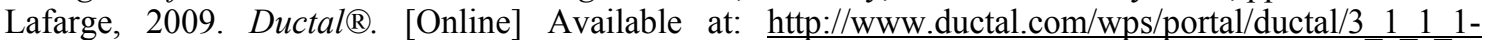
Detail?WCM_GLOBAL CONTEXT=/wps/wcm/connectlib ductal/Site ductal/English version/Page. Navigation.Architectural.BuildingEnvelopes.PerforatedFacades/KeyProjectDuctal\%20Page/KeyProjec tDuctal 1276026636950\#edito[Accessed 2016].

Lafarge, 2013. STUDIO Joran Briand. [Online] Available at: http://joranbriand.com/en/stade-jean-bouin/[Accessed 2016].

Perry, V. H. \& Seibert, P. J., 2008. The Use of UHPFRC (Ductal ${ }^{\circledR)}$ for Bridges in North America: The Technology, Applicationsand Challenges Facing Commercialization. Kassel, Kassel University Press, p. 815-822.

Perry, V., Scalzo, P. \& Weiss, G., 2007. Innovative Field Cast UHPC Joints for Precast Deck Panel Bridge Superstructures-CN Overhead Bridge at Rainy Lake, Ontario. Phoenix, AZ, s.n.

Rebentrost, M. \& Wight, G., 2008. Experience and Applications of Ultra-high Performance Concrete in Asia. Kassel, Germany, kassel university press.

Resplendino, J., 2004. First recommendations for Ultra-High-Performance Concretes and examples of application. Kassel, Germany, Kassel University Press, pp. 79-90.

Richard, P. \& Cheyrezy, M., 1995. Composition of Reactive Powder Concretes. Cement and Concrete Research, 25(7), pp. 1501-1511.

Taylor, H., Famy, C. \& Scrivener, K., 2001. Delayed Ettringite Formation. Cement and Concrete Research, Volume 31, pp. 683-693.

Vicenzino, E. et al., 2005. First use of UHPFRC in thin precast concrete roof shell for Canadian LRT station. PCI Journal, 50(5), pp. 50-67.

Voo, Y. L. \& Foster, S. J., 2010. Characteristics of ultra-high performance 'ductile' concrete and its impact on sustainable construction. The IES Journal Part A: Civil \& Structural Engineering, 3(3), pp. 168-187.

Voo, Y. L., Foster, S. J. \& Gilbert, R. I., 2006. Shear strength of fiber reinforced reactive powder concrete prestressed girders without stirrups. Journal of Advanced Concrete Technology, 4(1), pp. 123-132.

Wille, K., Naaman, A. E., El-Tawil, S. \& Parra-Montesinos, G. J., 2012. Ultra-high performance concrete and fiber reinforced concrete: achieving strength and ductility without heat curing. Materials and Structures, Volume 45, p. 309-324. 